\title{
Using Flipped Learning Model in Teaching English Language among Female English Majors in Majmaah University
}

\author{
Bothina S. M. Abdelshaheed ${ }^{1}$ \\ ${ }^{1}$ College of Education in Zulfi, Majmaah University, 11952, Saudi Arabia \\ Correspondence: Bothina S. M. Abdelshaheed, College of Education in Zulfi, Majmaah University, 11952, Saudi \\ Arabia \& College of Education in New Valley, Assiut Uinversity, Egypt. E-mail: bothinashaheed@gmail.com
}

\author{
Received: August 26, 2017 Accepted: October 10, 2017 Online Published: October 12, 2017 \\ doi: 10.5539/elt.v10n11p96 URL: http://doi.org/10.5539/elt.v10n11p96
}

\begin{abstract}
This study aims at investigating the effect of using Flipped Learning Model in teaching English language among female English majors in Majmaah University on their achievement in two different English courses and identifying their feelings and satisfaction about flipping their classes. The study used a pre-post test design and included two experimental groups $(\mathrm{n}=62)$. A comparison of students' scores in pre and post experimentation were carried to identify the effect of the model and size of improvement in students' achievement. An analysis of students' responses to an online questionnaire was conducted to reveal their feelings towards the flipped model. Results affirmed the hypotheses of the study and there was a significant higher improvement in students' scores in post-tests. Students also favored the flipped learning model and had positive feelings towards it.
\end{abstract}

Keywords: flipped learning, English language teaching, learning models

\section{Introduction}

Most teachers of TEFL from kindergartens to college level are enthusiastic and completely eager to the idea of changing their classes into an excited learning environment that provides students with more structure and independence to construct knowledge in a constructivist learning setting with the teacher as a facilitator and supervisor. However, many of them are uncertain about the suitable strategy. Some teaching and learning methods- like social constructivist learning, problem solving, collaborative learning and blended learning can satisfy these needs. The basic idea is to change the roles and involve the learners more. The current mentioned trends focus on rearranging teaching practices and activities in a way that transfers responsibility and ownership of learning from the teacher into the students, and creates a learning environment where teachers are no longer dispensers of knowledge but rather guides and directors while students are the real active constructors of knowledge.

\subsection{Flipped Learning}

The Flipped Learning Model as a growing trend in education rests on changing the roles of both teachers and students by inviting students to attempt to pre-learn a topic prior to the in-class instruction. The idea behind flipped learning is to fill the freed class time with more interactive and collaborative learning activities. According to Berrett (2012), it is "rapidly expanding to mean any approach that requires students to prepare outside of class for active participation in class" (Berrett, 2012). This of course requires instructors to design more learning and teaching materials and students to work on more activities and show more efforts and involvement.

Regarding English language learning and teaching, the flipped learning model hangs on adopting many techniques that allow students to be more interactive inside the class and have wider opportunities that "can help English language learners further develop their academic language proficiency and confidence in using the language" (Marshall \& DeCapua, 2013). Compared to lecturing, flipped learning makes a difference. In traditional lecturing classrooms, English language learners "put most of their effort into the lower levels of Bloom's Taxonomy-understanding and remembering-as they attempt to follow the teacher's instructional delivery" Marshall and DeCapua (2013). The problem of the face-to-face lecture as a learning context that it is "insufficient, fast, one-sided and too rapid to allow skill processing and students rarely have time enough to process ideas and move them toward long-term memory before new ideas presented in lecture displace them. By 
using lectures as the first tool to expose students to content, teachers waste the most valuable chance, commodity and ability to guide students. Classes should pose question, exercises, problems and solutions to help students process new content and activate their prior knowledge" (Hodges, 2015). It is clear then that flipping the class allows the teacher to move lower levels of the Bloom's taxonomy to outside the classroom to another context in which students have time and space to work on understanding the new concepts. Flipped learning model depends on both curricular in-class activities and extra-curricular out-class activities. According to Hamdan N., McKnight P., McKnight K. and Arfstrom K. (2013), "just as no two traditional classrooms are identical, such is the case with flipped classrooms". It means that in-class and out-class activities vary according to the nature of topics covered and students' level, but still they share the same core. It is simply described by Herreid and Schiller (2013: 62) as "what is normally done in class and what is normally done as homework is switched". This means that the core notion of the flipped classroom is to flip long-established type of learning so that the work that is habitually done at home is completed in the classroom, while the material that is habitually learned in the classroom is completed at home by the students.

\subsection{The Effective Tools of Flipped Learning Model}

Flipped learning model depends basically on using some functioning digital technologies and tools like videos, presentations and websites, but videos are the golden technology that flipped learning uses. They are easy-to-make, popular and available everywhere. The teacher is responsible for providing learning resources in the flipped learning model whether by designing them him/herself or assigning them on the world wide web. These resources should be conditionally high quality-prepared, simply-designed and related to the educational targeted content. Miller (2012) suggested that teachers should not "make epic videos that last hours as keeping the learning within the videos manageable for students will help formatively ensure learning and it will feel doable for students" (Miller, 2012).

Flipped Learning share the same technological tools with different leaning models and it has been compared to online, blended, and distance learning because of the technical components. Still there are many sharp clear differences among these models. One important distinguishing difference is that in-class practices and activities represent an inspirable part of the flipped classroom. Blended classes also have an online element, but that usually occurs during class time along with direct student-teacher contact (Allen, Seaman, \& Garrett, 2007), when the online practice of the flipped learning occurs separately from the in-class practice.

\subsection{The Saudi Teaching Context and Flipped Classroom}

Integrating technology in teaching English language has become an inspirable parcel of today teaching and learning environments. Of course, Saudi educational institutions are not an exception; on the contrary, they have embarked on the technological tools in different ways to take advantage of their valuable benefits in teaching and learning.

Many Saudi studies investigated the efficacy of technology inclusion in education to offer more expanded opportunities for students' exposure to the target language and also promote self-learning skills. These studies have shown a significant effect of integrating technology in teaching English language on students' English proficiency levels and attitudes towards learning English (Al-Shehri, 2011, Al-Okaily, 2013, AlRowais, 2014, Al-Harbi, 2015, Al-Kathiri, 2015; Alresheed, Leask, \& Raiker, 2015, Al-Harbi \& Alshumaimeri, 2016, Al-Otaibi, 2016; Al-Zahrani, 2015).

Inspite of its recent inception, Majmaaah University successfully adopted a very new and effective channel of Online learning platform called Desire to Learn System (D2L) across all academic departments. English Department is not also an exception. This research aimed at investigating the effect of applying the flipped learning model using this technical education system as an alternative to the traditional lecturing class in teaching English language to hopefully enhance the acquisition of academic knowledge and proficiency of two English courses among prospective Female English Language Teachers. This online platform functions as the outside context in which students have the chance to read, watch and interact with learning materials. They can repeat them countless times to get theoretical knowledge that qualifies them to the face-to-face practice and exercises in the class. By doing this, they are encouraged to do the outside classwork according to their own learning speed using the materials they have online which is one of the important pillars of the successful flipped classroom.

\section{Literature Review}

The recognizable shift documented by a number of studies towards the online learning paved the way for the emerging of Flipped Learning Model. It is one of the growing models of teaching and learning that integrates 
technology in teaching and at the same time allows knowledge acquisition to occur in a differentiated manner inside the class without sending the teacher outside the circle of learning. The definition of a flipped classroom is also rapidly expanded to relate to any approach that requires students to prepare outside of class for active participation in class (Berrett, 2012)

The two teachers recognized as the pioneers of Flipped Learning, Jonathan Bergmann and Aaron Sams, started their first experimenting of Flipped learning in 2007. They wrote a book titled "Flip Your Classroom: Reach Every Student in Every Class Every Day" (2012) in which they reported flipping their classrooms. When their students began interacting more in class, Sams and Bergmann (2012) were motivated by this appealing success to start the not-for-profit Flipped Learning Network ${ }^{\mathrm{TM}}$ (FLN). The book goals are to provide professional learning opportunities on Flipped Learning; to conduct, collaborate and disseminate relevant research on Flipped Learning; and to act as the clearinghouse for distributing best promising practices for current and future educators (Hamdan et al., 2013).

Although flipped learning is a hot topic in education right now, it is not a new idea. "In the early 19th century, General Sylvanus Thayer created a system at West Point where engineering students, given a set of materials, were responsible for obtaining core content prior to coming to class. The classroom space was then used for critical thinking and group problem solving". (Musallam, 2011).

There is a growing interest in verifying the effectiveness of the key elements of Flipped Learning Model both qualitatively and quantitatively. Most of these research efforts are built upon authenticating the instructional basics and pillars on which Flipped Learning depends like Blended Learning, Constructivist Learning, Active leaning and most of the student-centered approaches that allow students to work more and teachers to guide more.

Reviewing the body of research conducted about Flipped Learning, it was found that it has its own remarkable rank among effective models of teaching Science, Math, Engineering and Medical Sciences. (Chaplin, 2009, Brent \& Felder 2012, Freeman, Eddy, McDonough, Smith, Okoroafor, Jordt, \& Wenderoth, 2014). The number of the systematic studies investigating its effectiveness as higher education teaching model is limited and small, but there was a wide-range study in Fall 2012 as over 466,000 K-12 students, parents, teachers, and administrators participated in the annual Speak Up online surveys facilitated by the national education nonprofit organization, Project Tomorrow $\mathbb{C}$. Specific questions about Flipped Learning were asked for the first time in that survey. The survey defined Flipped Learning as a model in which students watched instructional videos as homework and class time was used for "discussions, projects, experiments and to provide personalized coaching to individual students." Of the more than 56,000 teachers and librarians who responded, $6 \%$ indicated they were using videos they found online and 3\% said they had already created videos as part of flipping their classroom. The survey also found that $18 \%$ of teachers and $27 \%$ of administrators said they were interested in trying Flipped Learning this year. Twenty percent of teachers said they wanted to learn more about how to create instructional videos for their students to watch and $15 \%$ wanted to learn how to implement a flipped classroom model. Nearly $60 \%$ of the students in grades 6-12 who participated in the Speak Up survey agreed with the statement that Flipped Learning "would be a good way for me to learn." Teachers who have implemented Flipped Learning also report feeling re-energized by their heightened interaction with students (Baker, 2012).

In a comprehensive survey of prior and ongoing research of the flipped classroom conducted by Bishop and Verlager (2013), they show that most studies conducted to explore student perceptions, and used single-group study designs. The survey Reports that student perceptions of the flipped classroom are somewhat mixed, but are generally positive overall and students prefer in-person lectures to video lectures, but prefer interactive classroom activities over lectures. The studies surveyed suggest that student learning is improved for the flipped compared to traditional classroom. They also revealed that very little objective investigations of student learning outcomes were carried. It recommended for future studies investigating objective learning outcomes using experimental or quasi-experimental designs and also recommended that researchers should consider the theoretical framework used to guide the design of in-class activities (Bishop \& Verlager, 2013).

There is little rigorous empirical research on the effects of using Flipped Learning model in teaching foreign languages, not only in the middle east where the current study is conducted, but all over the world. Rodríguez (2014) conducted a study to evaluate the results of introducing the flipped classroom methodology in a secondary school. The study also showed that the flipped classroom leads to the acquisition of social and personal values and positive attitudes such as solidarity and helping the others. Ahmed's study (2016) concluded that the flipped classroom had a significant effect on the listening comprehension of Egyptian EFL students. The current study builds on these results and investigations aiming at examining the effect of flipping some English 
language classes.

\section{Methods}

\subsection{Aims of the Study}

The current study aimed at two main goals; first, evaluating the results of using the flipped learning model in teaching English among female English majors, and second, analyzing students' feelings and satisfaction towards using the flipped learning model in learning.

\subsection{Hypotheses of the Study}

The study hypothesized that (a) there would be a statistically significant difference between the mean scores obtained by female students of the first experimental group in the pre-test and the post test of Teaching English language course favoring the post-test; (b) there would be a statistically significant difference between the mean scores obtained by female students of the second experimental group in the pre-test and the post test of Advanced Writing course favoring the post-test; (c) there would not be any statistically significant difference between the mean scores obtained by female students of the first experimental group and those of the second experimental group in the post-tests due to the nature of the two courses, (d) and finally there would be a positive attitude toward the flipped learning model among the female students of the two experimental groups.

\subsection{Study Design}

The study included the quantitative method employed with pre-post testing to the two experimental groups to identify the effect of the independent variable - using flipped learning- on the two dependent variables- students' academic achievement in both courses and their satisfaction about the experiment. Pre-tests and post-tests were used to the different experimental groups. A comparison of the two groups' scores in the pre-post tests were carried to identify the effect of the model and size of improvement in students' achievement.

\subsection{Participants}

This study was carried out in 2016-2017 academic year in The English language Department, female section, in Zulfi College of Education, Majmaah University. The study was conducted in parallel across two English courses; Advanced Writing ( $\mathrm{n}=33$ students in Level 5 as the $1^{\text {st }}$ experimental group) and Teaching English Language ( $\mathrm{n}=29$ students in level 8 as the $2^{\text {nd }}$ experimental group). They represented two experimental groups who studied the courses using the flipped learning model and were taught by the researcher. The purpose was to have different groups with two different courses to identify any differences due to the students level or course nature and to reach more confirmation that the flipped learning model can succeed with both productive ( advanced writing) and practical (Teaching English as a Foreign Language) courses at university level. Both classes were met once a week for three hours per week over 15 weeks. None of the students had ever taken a flipped class before, but just about 30 percent had taken some online courses prior to this course.

Table 1. The study design of the groups

\begin{tabular}{|c|c|c|c|c|c|}
\hline Groups & Area of Content & No. & Pre-Testing & Experiment & Post-Testing \\
\hline Experimental 1 & $\begin{array}{l}\text { English } \\
\text { Teaching }\end{array}$ & 29 & -Achievement Test & $\begin{array}{ll}\text { Flipping } & \text { The } \\
\text { Classroom } & \end{array}$ & $\begin{array}{l}\text {-Achievement Test } \\
\text {-Survey }\end{array}$ \\
\hline Experimental 2 & Advanced Writing & 33 & $\begin{array}{l}\text {-Achievement Test } \\
\text { - }\end{array}$ & & $\begin{array}{l}\text {-Achievement Test } \\
\text {-Survey }\end{array}$ \\
\hline
\end{tabular}

\subsection{Tools of the Study}

\subsubsection{Pre-post English Language Test}

The test aimed at measuring students' knowledge of teaching English Language Methodology. It included different types of questions; MCQ, True or False Questions, Filling the gaps, short answer question and producing a lesson plan. The validity of the test was approved and validated by a panel of TEFL experts and some revision was done in light of the panel's comments. The reliability of the test was estimated by using a test-re-test method. It was administered twice to a group of English language majors and the stability coefficient was decided on by calculating the correlation between the students' scores on the two administrations using Pearson product moment 
correlation formula. The reliability of this test was found $(\mathrm{r}=.77)$. The total score of the test was 60 point.

\subsubsection{Pre-post Advanced Writing Test}

The test aimed at measuring students' knowledge and skill of writing. It included True or False question, filling the gaps, writing a paragraph and writing an essay. A panel of TEFL experts was relied on for their opinions on the appropriateness and validity of the test. Test-retest reliability was achieved through administering the test twice using Pearson product moment correlation formula. The reliability of this test was found $(r=.76)$. The total score of the test was 60 point. Two raters scored each student's paper using a five-point scoring scale and the final score on this test was the mean score given by the two raters

\subsubsection{Online Survey}

As an online survey was applied to obtain data about students' feeling and satisfaction about the experiment of flipping their classes. It contained 13questions requiring students to choose from a 5-point Likert scale statement and two open-ended questions required stating their opinions and feelings. A panel of TEFL experts was relied on for their opinions on the appropriateness and validity of the survey. It was conducted using the online learning platform D2L.

\section{Findings}

Finding of the study were explained in light of the four hypotheses of the study as follows:

Hypothesis (a) indicated that there would be statistically significant difference between the mean scores obtained by female students of the first experimental group in the pre-test and the post test of Teaching English language course favoring the post-test. Table ( 2 ) shows a comparison of the mean scores of the students. According to the table, the first hypothesis is affirmed.

Table 2. "T" value, standard deviations and Means of scores female students of the first experimental group in the pre-test and the post test of Teaching English language course

\begin{tabular}{lllllll}
\hline Data Group & N & Final Score & M & SD & “T” value & Significance \\
\hline $1^{\text {st }}$ experimental & 29 & 60 & 33.07 & 1535.86 & 24.04 & significant on level $(0,01)$ \\
\hline
\end{tabular}

Hypothesis (b) indicated that there would be statistically significant difference between the mean scores obtained by female students of the second experimental group in the pre-test and the post test of Advanced Writing course favoring the post-test. Table 3 shows a comparison of the mean scores of the students. According to the table, the first hypothesis is affirmed.

Table 3. "T" value, standard deviations and Means of scores female students of the second experimental group in the pre-test and the post test of advanced writing course

\begin{tabular}{lllllll}
\hline Data Group & $\mathrm{N}$ & Final Score & $\mathrm{M}$ & $\mathrm{SD}$ & "T” value & Significance \\
\hline $2^{\text {nd }}$ experimental & 33 & 60 & 23.33 & 1785.83 & 17.94 & significant on level $(0,01)$ \\
\hline
\end{tabular}

Hypothesis (c) indicated that there would not be any statistically significant difference between the mean scores obtained by female students of the first experimental group and those of the second experimental group in the post-tests due to the nature of the two courses. Table 4 shows a comparison of the mean scores of the students. According to the table, the first hypothesis is affirmed.

Table 4. "T" value, standard deviations and Means of scores female students of the two experimental groups in the post-tests of the two courses

\begin{tabular}{llllll}
\hline Data Group & $\mathrm{N}$ & $\mathrm{M}$ & $\mathrm{SD}$ & “T” value & Significance \\
\hline $1^{\text {st }}$ experimental & 29 & 46.48 & 9.07 & & \\
$2^{\text {nd }}$ experimental & 33 & 50.35 & 10.26 & 1.54 & Insignificant on level $(0,01)$ \\
\hline
\end{tabular}


Hypothesis (d) indicated that there would be a positive attitude toward the flipped learning model among the female students of the two experimental groups. The female students in both assigned classes were asked for their feedback at the end of the experiment. All students in the two classes $(n=62)$ responded to the online survey. Means and standard deviations of students' responses to the questionnaire in the two groups were calculated as indicated in the Tables 5 and 6 .

Table 5. Means and standard deviations of the responses of female students of the $1^{\text {st }}$ experimental group in the questionnaire of satisfaction towards the flipped learning model

\begin{tabular}{|c|c|c|c|c|c|c|c|c|c|c|c|c|c|c|c|}
\hline 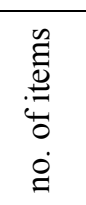 & 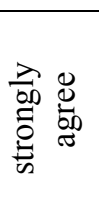 & 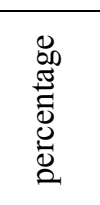 & $\underset{\varpi}{\stackrel{8}{\leftrightarrows}}$ & 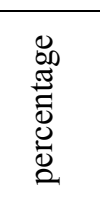 & 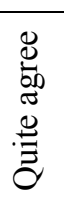 & 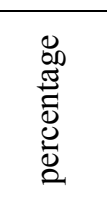 & 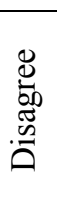 & 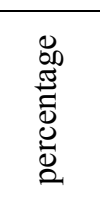 & 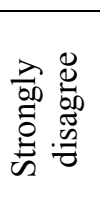 & 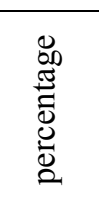 & 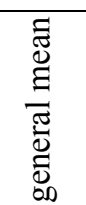 & 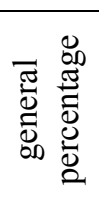 & के & $\begin{array}{l}\text { है } \\
\text { 乞ี }\end{array}$ & 兽 \\
\hline 1 & 3 & 10.34 & 2 & 6.90 & 3 & 10.34 & 10 & 34.48 & 11 & 37.93 & 2.17 & 43.45 & 1.29 & 11 & Disagree \\
\hline 2 & 20 & 68.97 & 4 & 13.79 & 1 & 3.45 & 2 & 6.90 & 2 & 6.90 & 4.31 & 86.21 & 1.23 & 3 & $\begin{array}{c}\text { strongly } \\
\text { agree }\end{array}$ \\
\hline 3 & 17 & 58.62 & 7 & 24.14 & 2 & 6.90 & 2 & 6.90 & 1 & 3.45 & 4.28 & 85.52 & 1.08 & 4 & $\begin{array}{c}\text { strongly } \\
\text { agree }\end{array}$ \\
\hline 4 & 17 & 58.62 & 7 & 24.14 & 2 & 6.90 & 2 & 6.90 & 1 & 3.45 & 4.28 & 85.52 & 1.08 & 4 & $\begin{array}{c}\text { strongly } \\
\text { agree }\end{array}$ \\
\hline 5 & 18 & 62.07 & 7 & 24.14 & 1 & 3.45 & 2 & 6.90 & 1 & 3.45 & 4.34 & 86.90 & 1.06 & 2 & $\begin{array}{c}\text { strongly } \\
\text { agree }\end{array}$ \\
\hline 6 & 18 & 62.07 & 9 & 31.3 & 0 & 0 & 1 & 3,45 & 1 & 3.45 & 4.45 & 88.97 & 0.93 & 1 & $\begin{array}{c}\text { strongly } \\
\text { agree }\end{array}$ \\
\hline 7 & 10 & 34.48 & 9 & 31.3 & 1 & 3,45 & 6 & 20.69 & 3 & 10.34 & 3.59 & 71.72 & 1.40 & 8 & agree \\
\hline 8 & 17 & 58.62 & 4 & 13.79 & 2 & 6.60 & 4 & 13.79 & 2 & 6.90 & 4.03 & 80.69 & 1.35 & 6 & agree \\
\hline 9 & 2 & 6.90 & 1 & 3045 & 8 & 27.59 & 11 & 37.93 & 7 & 24.14 & 2.31 & 46.21 & 1.09 & 10 & Disagree \\
\hline 10 & 4 & 13.79 & 1 & 3.45 & 8 & 27.59 & 9 & 31.03 & 7 & 24.14 & 2.52 & 50.34 & 1.28 & 9 & Disagree \\
\hline 11 & 15 & 51.72 & 5 & 17.24 & 4 & 13.79 & 4 & 13.79 & 1 & 3.45 & 4.00 & 80.00 & 1.23 & 7 & agree \\
\hline 12 & 15 & 51.72 & 5 & 17.24 & 4 & 13.79 & 4 & 13.79 & 1 & 3.45 & 4.00 & 80.00 & 1.23 & 7 & agree \\
\hline 13 & 16 & 55.17 & 7 & 24.14 & 3 & 10.34 & 3 & 10.34 & 0 & 0 & 4.24 & 84.83 & 1.01 & 5 & $\begin{array}{c}\text { strongly } \\
\text { agree }\end{array}$ \\
\hline total & 172 & 45.62 & 68 & 18.04 & 39 & 10.34 & 60 & 15.92 & 38 & 10.08 & 3.73 & 74.64 & 1.43 & & agree \\
\hline
\end{tabular}

Table 6. Means and standard deviations of the responses of female students of the $2^{\text {nd }}$ experimental group in the questionnaire of satisfaction towards the flipped learning model

\begin{tabular}{|c|c|c|c|c|c|c|c|c|c|c|c|c|c|c|c|}
\hline 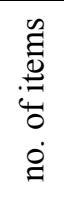 & 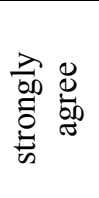 & 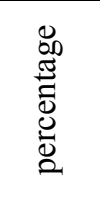 & 总 & 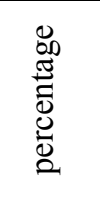 & 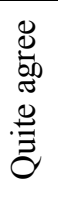 & 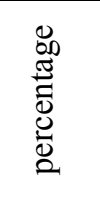 & 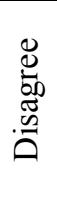 & 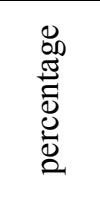 & 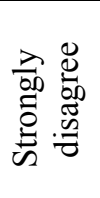 & 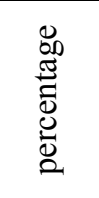 & 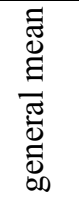 & 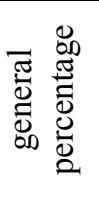 & 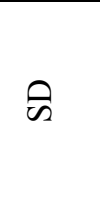 & 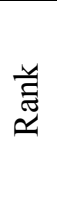 & 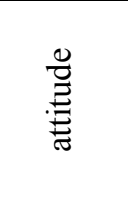 \\
\hline 1 & 7 & 21.21 & 1 & 3.03 & 8 & 24.24 & 10 & 30.30 & 7 & 21.21 & 2.73 & 54.55 & 1.40 & 9 & $\begin{array}{l}\text { Quite } \\
\text { agree }\end{array}$ \\
\hline 2 & 16 & 48.48 & 5 & 15.15 & 3 & 9.09 & 6 & 18.18 & 3 & 9.09 & 3.76 & 75.15 & 1.44 & 5 & Agree \\
\hline 3 & 16 & 48.48 & 4 & 12.12 & 4 & 12.12 & 6 & 18.18 & 3 & 9.09 & 3.73 & 75.55 & 1044 & 6 & Agree \\
\hline 4 & 23 & 69.70 & 7 & 21.21 & 2 & 6.06 & 1 & 3.03 & 0 & 0.00 & 4.58 & 91.52 & 0.74 & 1 & $\begin{array}{c}\text { strongly } \\
\text { agree }\end{array}$ \\
\hline 5 & 17 & 51.52 & 5 & 15.15 & 4 & 12.12 & 4 & 12.12 & 3 & 9.09 & 3.88 & 77.58 & 1.39 & 3 & Agree \\
\hline
\end{tabular}




\begin{tabular}{|c|c|c|c|c|c|c|c|c|c|c|c|c|c|c|c|}
\hline 6 & 20 & 60.61 & 10 & 30.30 & 0 & 0.00 & 2 & 6.06 & 1 & 3.03 & 4.39 & 87.88 & 0.98 & 2 & $\begin{array}{l}\text { strongly } \\
\text { agree }\end{array}$ \\
\hline 7 & 10 & 30.30 & 10 & 30.30 & 1 & 3.03 & 7 & 21.21 & 5 & 15.15 & 3.39 & 67.88 & 1.48 & 8 & $\begin{array}{l}\text { Quite } \\
\text { agree }\end{array}$ \\
\hline 8 & 17 & 51.52 & 5 & 15.15 & 4 & 12.12 & 4 & 12.12 & 3 & 9.09 & 3.88 & 77.58 & 1.39 & 3 & agree \\
\hline 9 & 7 & 21.21 & 1 & 3.03 & 8 & 24.24 & 10 & 30.30 & 7 & 21.21 & 2.73 & 54.55 & 1.40 & 9 & $\begin{array}{l}\text { Quite } \\
\text { agree }\end{array}$ \\
\hline 10 & 7 & 21.21 & 1 & 3.03 & 8 & 24.24 & 10 & 30.30 & 7 & 21.21 & 2.73 & 54.55 & 1.40 & 9 & $\begin{array}{l}\text { Quite } \\
\text { agree }\end{array}$ \\
\hline 11 & 17 & 51.52 & 5 & 15.15 & 4 & 12.12 & 4 & 12.12 & 3 & 909 & 3.88 & 77.58 & 1.39 & 3 & agree \\
\hline 12 & 13 & 39.39 & 10 & 30.30 & 4 & 12.12 & 3 & 9.09 & 3 & 9.09 & 3.88 & 76.36 & 1.29 & 4 & agree \\
\hline 13 & 14 & 42.42 & 10 & 30.30 & 2 & 6.06 & 3 & 9.09 & 4 & 12.12 & 3.82 & 76.36 & 1.38 & 4 & agree \\
\hline total & 184 & 42.89 & 74 & 17.25 & 52 & 12.12 & 70 & 16.32 & 49 & 11.42 & 3.64 & 72.77 & 1.45 & 7 & agree \\
\hline
\end{tabular}

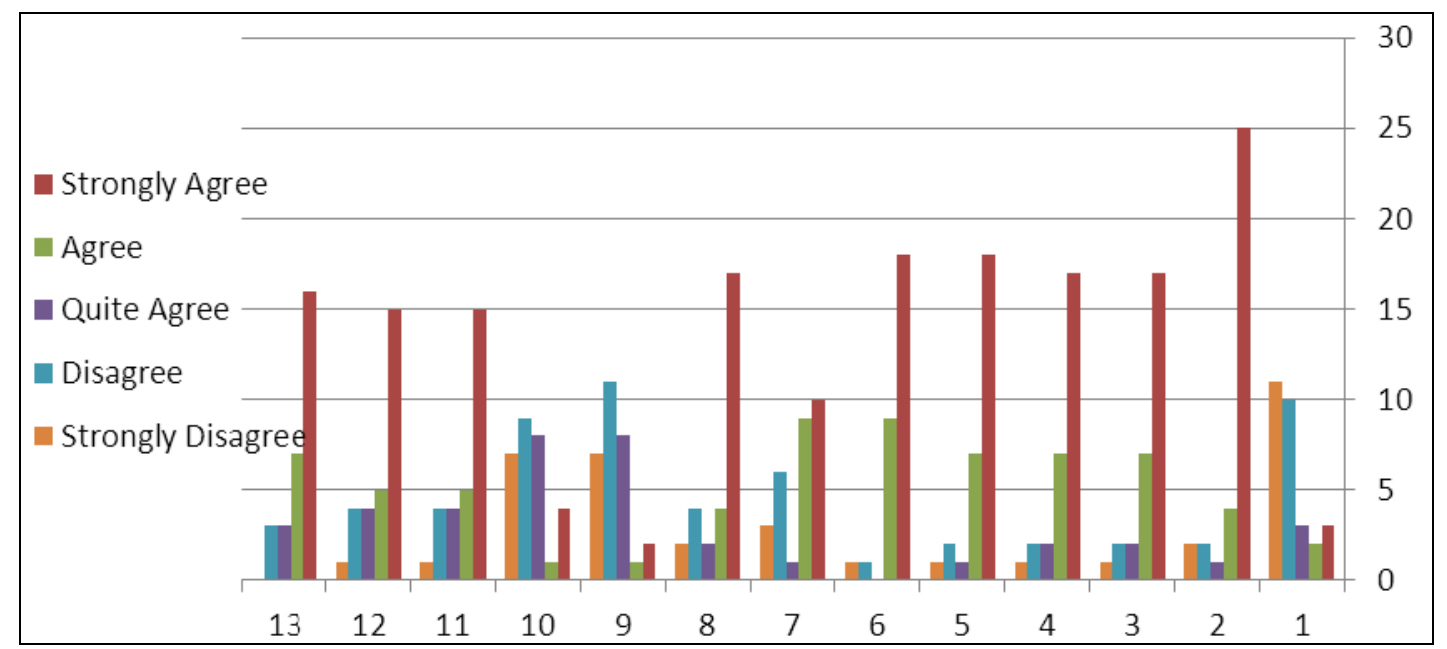

Figure 1. First group's responses to the survey (Teaching English Language Course) $n=29$

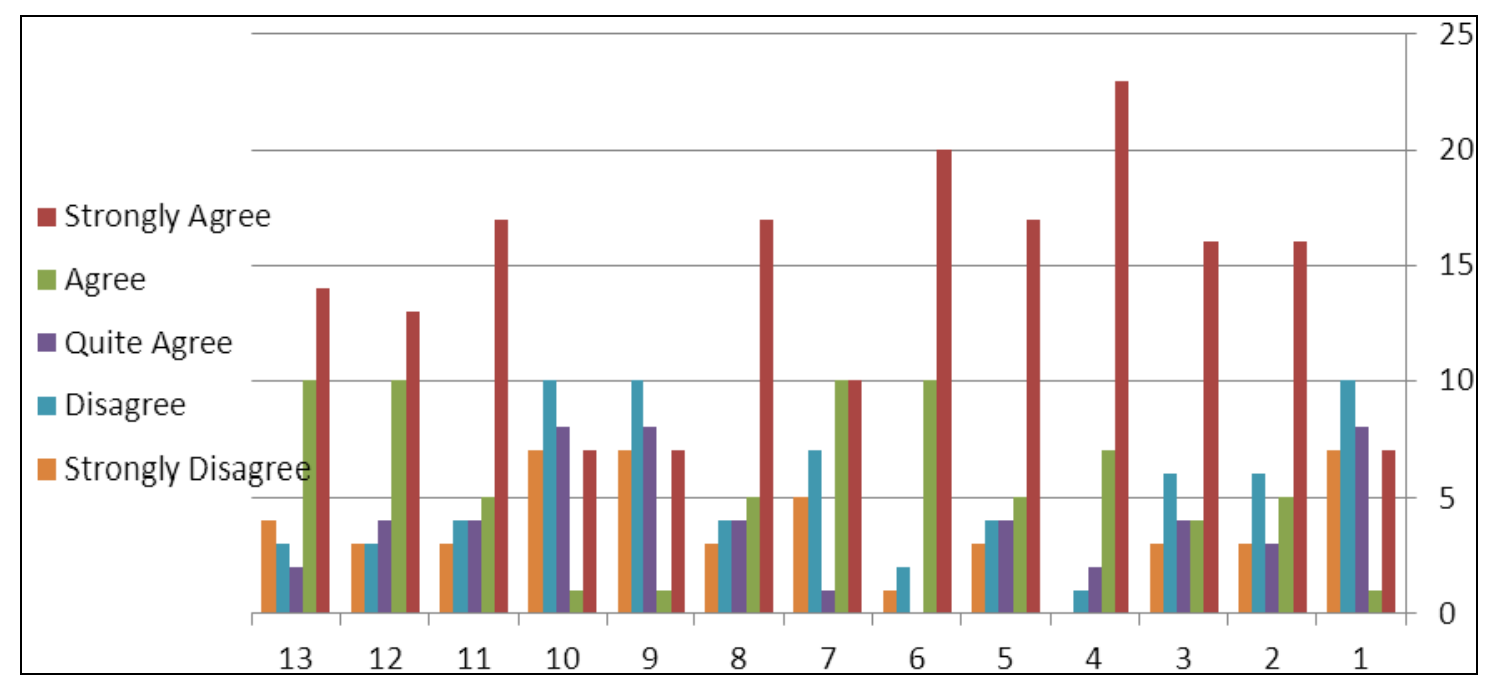

Figure 2. Second group's responses to the survey (Advanced Writing Course) $n=33$ 


\section{Discussion and Interpretations}

Results of the present study are in line and compatible with many previous studies (Baker, 2012, Berrett, 2012, Driscoll, 2012, Hamdan et al., 2013, Bishop \& Verlager, 2013, Al-Harbi, 2015, AlRowais, 2014, Rodríguez, 2014, Al-Zahrani, 2015, Ahmed, 2016).

The first and second results indicate that the mean scores of the two experimental group students in the achievement post-tests are remarkably high as indicated in Table 4 and this is due to the effectiveness of flipping the teaching and learning process from a teacher-centered process into a student-centered one. Flipped learning increased the continual and positive interaction among the teacher and students, provide students with more access to learning materials and consequently increase their academic achievement. The current study actually builds on inverting the two main phases of acquiring knowledge; (a) transmission that happens through lectures and is represented in the two lowest levels of Bloom's Cognitive taxonomy; Knowledge and Comprehensionand (b) assimilation that happens through many activities like homework, lab work, cooperative learning and projects and is represented in the four upper levels; Application, Analysis, Synthesis and Evaluation. When the classroom was flipped, the two phases were inverted as assimilation happened during class time when the students had the heaviest cognitive load and the most accessibility of the teacher, and transmission happened before the class when students had the lowest cognitive duties with the least accessibility of the teacher. This result goes in line with some studies (Bergmann \& Sams, 2009, Fulton, 2012, Alvarez, 2011, Siegle, 2013).

The third result indicates that there are no significant differences between the mean scores of the $1^{\text {st }}$ experimental group students and those of the $2^{\text {nd }}$ experimental group. Students' scores are high in both groups and this is due to the active and constructivist mode of the flipped learning. In the current study, one important benefit of teaching the two courses via flipped leaning is "the greater gains in conceptual understanding" (Berrett, 2012). These courses require much time from the students to read and understand many theoretical principle concepts like phases of writing process, essay writing elements and methods and techniques of teaching English as a foreign language. At the same time, students need more time to apply these concepts, produce written texts, design lesson plans, hold micro teaching sessions, and complete many different tasks. Lecturing only is not such a good technique that suits teaching all these productive skills. However, in the current study, flipping the process of teaching and learning was effective in many ways; first it provided the students with the time they need to understand and the space they need to practice. Second it resulted in exponential increase in students' involvement and activeness in learning as they have complete ownership and responsibility towards their learning. Third it offered a potential benefit of providing students with immediate feedback and discussion about their work and assignments which enabled them to achieve higher understanding of concepts and mastery of skills.

The fourth result reveals that students in both groups have a high satisfaction and positive attitude towards the flipped learning model. Some studies affirm the same result (McLaughlin, Roth, Glatt, Gharkholonarehe, Davidson, Griffin, Esserman, \& Mumper 2014, Jensen, Kummer, \& Godoy 2015). Date in the Tables 5 and 6 clarifies that the students in both groups favored flipping their classes and their total attitude is Agree. Analyzing students' responses to the questionnaire shows that students find a suitable and safe environment to learn. Most of the students in the 1st group (86.28\%) and the 2nd group (75.15\%) liked having the lecture out of the class time. They found the flipped class time more useful, liked the flipped class and agreed to have more flipped classes in the future $\left(1^{\text {st }}\right.$ and $2^{\text {nd }}$ groups respectively $80 \%, 76.36 \%$ ). The two open-ended questions allowed students to describe their feelings anonymously and plainly. They reported what they most liked and disliked in their flipped learning experience. They liked the interactive nature of the classes, the easy access to the teacher during practice and tasks, considering their strengths and weaknesses, constant feedback and correction

Hence, it can be easily observed that the flipped classroom leads to meaningful learning, and this opens the door to frequently adopt it in our educational system as one of the effective teaching models. On the other hand, there are some challenges that faced the current study and require paving the field for flipping teaching and learning process.

It is well known that all teaching and learning techniques and approaches involve advantages and disadvantages. One major limitation of the flipped learning model is its dependence on the internet. Some learners, some girls in KSA universities, had the problem of poor or no access to the internet. This is due to some social or technical factors. However, this drawback was handled as Johnson (2012) suggested by burning DVDs for students with no computers, giving students a USB drive with the videos and providing supplementary access to the internet either in class or before, or during the school day. Thus, Students who are unable to watch the videos at home can watch the videos in school. Another limitations was represented in some students' attitudes towards the 
flipped classroom as an online-dependent learning model. Some of them were so careless to watch and read the online materials depending on the classwork to understand the topics. The teacher indirectly forced the students to complete the out-class work by asking them to submit and complete certain tasks after watching or reading the learning material; completing a quiz, answering a question or paraphrasing certain stanza. Johnson (2012) proposed that to force those students to watch the videos and read the materials, he "usually has the student watch the video in class while the other students are completing their daily learning tasks. These students normally realize, after a while, that their casual approach causes them to fall behind their classmates".

\section{Conclusions}

Clearly, there is a room for improvement in higher education's use of learning technologies as we move from course management systems to more interactive approaches (D. Oblinger \& J. Oblinger, 2005). Some teaching approaches that function technology deprive the student from their deserved face time with their teachers. Therefore, faculty and administrators must continue to make a concerted and sincere effort to offer real face-to-face time to students so that genuine, real-time discussions, which are often stifled online or over inbox communication, can occur" (Windham, 2005). The current study has taken a step toward providing some real and empirical data about the benefits of flipped learning model application. It was an attempt to open path in front of curriculum developers, teachers and researchers in Saudi Arabia to test and experiment some new trend in teaching to overcome the problems of lack of opportunities for language practice and teacher-led classes. Therefore, the current study was conducted on EFL female majors to investigate the effect of the flipped learning on students' achievement and attitudes. There is a growing body of research on using the Flipped Learning model with diverse student populations as well. More qualitative and quantitative research needs to be done to identify how the potential of the model can be maximized. (Hemdan et al., 2013).

It required much work and effort to flip two different classes for the first time. Designing learning materials and managing the classwork with the students who experiment flipped learning for the first time was not that easy. Instead, it was encouraging to consider what Marshall (2013) points out in her model of Flipped Learning, that one key role for teachers is to lead from behind. Thus, the teacher should think innovatively and try to find more options to solve the problems s/he may face by using every innovative device. In light of the current results, flipped learning that depends on integrating technical tools as means of content delivery can solve many educational problems.

\section{Acknowledgement}

This research is financed by the Deanery of Scientific Research at Majmaah University. The researcher would like to thank Majmaah University for its support.

\section{References}

Ahmed, S. (2016). The Flipped Classroom Model to Develop Egyptian EFL Students' Listening Comprehension. English Language Teaching, 9(9), 166-178. https://doi.org/10.5539/elt.v9n9p166

Al-Harbi, A. (2015). A Flipped Learning Approach Using Social Media in Health Informatics Education. Creative Education, 6(13), 1466-1475. http://dx.doi.org/10.4236/ce.2015.613147

Al-Harbi, S., \& Alshumaimeri, A. (2016). The Flipped Classroom Impact in Grammar Class on EFL Saudi Secondary School Students' Performances and Attitudes. English Language Teaching, 9(10), 61-80. https://doi.org/10.5539/elt.v9n10p60

Al-Kathiri, F. (2015). Beyond the classroom walls: Edmodo in Saudi secondary school EFL instruction, attitudes and challenges. English Language Teaching, 8(1), 189-204. https://doi.org/10.5539/elt.v8n1p189

Allen, I. E., Seaman, J., \& Garrett, R. (2007). Blending in: The extent and promise of blended education in the United States. Sloan Consortium.

Al-Okaily, R. (2013). Mobile learning and BYOD: implementations in an Intensive English Program. Learning and Teaching in Higher Education: Gulf Perspectives, 10(2). http://the.zu.ac.ae/index.php/lthehome/article/view/141/72

Alresheed, S., Leask, M., \& Raiker, A. (2015). Integrating Computer-Assisted Language Learning in Saudi Schools: A change model. Turkish Online Journal of Educational Technology, 14(4), 69.

AlRowais, A. S. (2014). The Impact of Flipped Learning on Achievement and Attitudes in Higher Education. International Journal for Cross-Disciplinary Subjects in Education, 4(1), 1914-1921. https://doi.org/10.20533/ijcdse.2042.6364.2014.0266 
Al-Shehri, S. (2011). Context in our pockets: Mobile phones and social networking as tools of contextualizing language learning. In 10th world conference on mobile and contextual learning, Beijing, China, October $18-21$.

Alvarez, B. (2011). Flipping the classroom: Homework in class, lessons at home. Education Digest: Essential Readings Condensed For Quick Review, 77(8), 18-21.

Al-Zahrani, A. (2015). From passive to active: The impact of the flipped classroom through social learning platforms on higher education students' creative thinking. British Journal of Educational Technology, 46(6), 1133-1148. https://doi.org/10.1111/bjet.12353

Baker, C. (2012). Flipped classrooms: turning learning upside down. Deseret News.

Bergmann, J., \& Sams, A. (2009). Remixing chemistry class: Two Colorado teachers make vodcasts of their lectures to free up class time for hands-on activities. Learning \& Leading with Technology, 36(4), 22-27.

Bergmann, J., \& Sams, A. (2012). Flip your classroom: Reach every student in every class every day. International Society for Technology in Education.

Berrett, D. (2012). How 'flipping' the classroom can improve the traditional lecture. The Education Digest, 78(1), 36.

Bishop, J., \& Verleger, M. (2013, June). The flipped classroom: A survey of the research. In ASEE National Conference Proceedings, Atlanta, GA, 30(9), 1-18.

Brent, R., \& Felder, R. M. (2012). Learning by solving solved problems. Chemical Engineering Education, 46(1), 29-30.

Chaplin, S. (2009). Assessment of the impact of case studies on student learning gains in an introductory biology course. Journal of College Science Teaching, 39(1), 72.

Driscoll, T. (2012). Flipped Learning and democratic Education. Graduate Thesis, Teachers College, Columbia University.

Freeman, S., Eddy, S., McDonough, M., Smith, M., Okoroafor, N., Jordt, H., \& Wenderoth, M. (2014). Active learning increases student performance in science, engineering, and mathematics. Proceedings of the National Academy of Sciences, 111(23), 8410-8415.

Fulton, K. (2012). Upside Down and inside out: Flip your classroom to improve student learning. Learning and Leading with Technology, 39(8), 12-17.

Hamdan, N., McKnight, P., McKnight, K., \& Arfstrom, K. (2014). A review of flipped learning. Flipped Learning Network 2013.

Herreid, C. F., \& Schiller, N. A. (2013). Case studies and the flipped classroom. Journal of College Science Teaching, 42(5), 62-66.

Hodges, L. C. (2015). Making Our Teaching Efficient: Flipping the Classroom. In The National Teaching and Learning Forum, 24(5), 1-4. https://doi.org/10.1002/ntlf.30033

Jensen, J., Kummer, T., \& Godoy, P. D. d. M. (2015). Improvements from a flipped classroom may simply be the fruits of active learning. CBE-Life Sciences Education, 14(1), ar5. https://doi.org/10.1187/cbe.14-08-0129

Johnson, G. (2012). Students, please turn to YouTube for your assignment. Education Canada, 52(5), 16-18.

Marshall, H. W. (2013, March 21). Three reasons to flip your classroom. Retrieved from http://www.slideshare.net/lainemarsh/3-reasons-to-flip-tesol-2013-32113

Marshall, H., \& DeCapua, A. (2013). Making the transition to classroom success: Culturally responsive teaching for struggling language learners. University of Michigan Press. https://doi.org/10.3998/mpub.4625213

McLaughlin, J., Roth, M., Glatt, D., Gharkholonarehe, N., Davidson, C., Griffin, L., ... \& Mumper, R. (2014). The flipped classroom: a course redesign to foster learning and engagement in a health professions school. Academic Medicine, 89(2), 236-243.

Miller, A. (2012). Five best practices for the flipped classroom. Edutopia. Posted online, 24, 02-12.

Musallam, R. (2011). Should you flip your classroom. http://www.edutopia.org/blog

Oblinger, D., \& Oblinger, J. (2005). Is it age or IT: First steps toward understanding the net generation. Educating the net generation, 2(1-2), 20. 
Patón Rodríguez, A. (2014) Flipped classroom and cooperative learning: a practical experience. Master's Degree in Secondary Education, Vocational Training and Language Teaching, University of Jaume 1.

Siegle, D. (2013). Technology: Differentiating Instruction by Flipping the Classroom. Gifted Child Today, 37(1), 51-55. https://doi.org/10.1177/1076217513497579

Windham, C. (2005). The Student's Perspective: Educating the Net Generation. Chapter 5. Educause E-book. pp. 50-65. Retrieved from https://net.educause.edu/ir/library/pdf/pub7101.pdf

\section{APPENDIX (1) English Language Teaching Test}

\section{Question One: $(10 \times 1.5=15$ Marks $)$}

Read and state whether the following items are true or false:

1) Songs provide safety because learners' mistakes are unnoticed. (...)

2) In copy writing activity, it isn't necessary for students to know what the sentences mean. (...)

3) Writing is a means to create ideas through two main stages. (...)

4) Listening selectively requires students to select what they are going to listen to. (......)

5) Cueing activities focus on elicitation. (......)

6) Giving instructions and asking questions should be in Arabic as much as possible. (......)

7) Listening is a receptive skill like reading that depends on comprehension. (......)

8) Simple statements are effective in showing the meaning of new vocabulary. (......)

9) Reading aloud promotes fun. (......)

10) Guessing activities are kinds of games. (......)

\section{Question Two: (12 $\times 1.5=18$ Marks $)$}

A- Select the suitable technique you can use to complete each of the following tasks:

1. To conduct a prewriting activities, you can use

$$
\text { (Reader's Theater- Brainstorming- Storytelling) }
$$

2. To write an objective, you can't use the verb

$$
\text { (define - translate - review) }
$$

3. To design an oral productive activity, you can use......

$$
\text { (dialogues- translation - copying) }
$$

4. To keep students' attention during reading, the teacher should

( pause during reading- avoid eye contact- let them stand up during reading)

5. To ask the students to immediately stop taking, you can teach them a

( signal - picture - map)

6. To practice controlled writing, you can use

(Reader's Theater - Table Composition - Reading Aloud) 
B- Select the correct action:

1- when using translation into learners' mother tongue you would....
a. give the Arabic equivalent to avoid wasting time.
b. Ask learners to give the Arabic equivalent by themselves.
c. Write translation on the board.
d. Use e-dictionary to translate.

2- When introducing the meaning of abstract vocabulary, you would better use...
a. Games
b. Imagined examples.
c. The Board
d. Realia

3- To create a zero noise level signal, ......

Question Three: $(2 \times \mathbf{2 . 5}=\mathbf{5}$ Marks $)$

A- How are pre-writing activities important? Give examples of these activities. sk.

B- Identify FOUR main characteristics of a good read-aloud story.

Question Four: (5 $\times \mathbf{2}=\mathbf{1 0}$ marks)

What are the solutions of the following problems?

1- The teacher shouts out in class.

2- The teacher has a noisy class and students shout out all time.

3- The teacher has a big number of students and can't remember their names.

4- The teacher doesn't use teaching aids.

5- The teachers ignores teaching listening because it is a difficult skill.

Question Five: (12 marks)

Use the following form to plan for teaching the attached lesson.

1- Objectives:

2- - Vocabulary \& Structures:

3- Materials and Teaching Aids

4- Presentation and Strategies used:

5- Assessment:

6- Homework

Best of Luck 
Question Three: $(2 \times 2.5=5$ Marks $)$

A- How are pre-writing activities important? Give examples of these activities.

B- Identify FOUR main characteristics of a good read-aloud story.

Question Four: (5 $\times 2=10$ marks)

What are the solutions of the following problems?

1- The teacher shouts out in class.

2- The teacher has a noisy class and students shout out all time.

3- The teacher has a big number of students and can't remember their names.

4- The teacher doesn't use teaching aids.

5- The teachers ignores teaching listening because it is a difficult skill.

Question Five: (12 marks)

Use the following form to plan for teaching the attached lesson.

1- Objectives:

2- - Vocabulary \& Structures:

3- Materials and Teaching Aids

4- Presentation and Strategies used:

5- Assessment:

6- Homework

Best of Luck

\section{APPENDIX (2) Advanced Writing Test}

Question One: $(10 \times 1=10$ Marks $)$

Read and state whether the following items are true or false:

1 - To organize your thoughts and ideas about a topic, you can use free writing. (.....)

2- People write to entertain others. (.....)

3- The first step of writing an essay is generating the ideas. (.......)

4- The last step of writing an essay is publishing. (.......)

5 - He audience is one of the factors to be considered when writing. (.......)

6- The purpose of writing doesn't affect the style or format of writing. (.....)

7 - In brainstorming, some irrelevant ideas must be deleted.

$(\ldots \ldots \ldots)$

8 - Clustering is very similar to brainstorming. (........)

9- The main idea of the paragraph is stated in the sentence topic. (.......)

10 -Clustering means writing the ideas that comes into your mind as quickly as the writer can.(...) 
Question Two: (10 Marks)

Fill the gaps using the terms below:

\begin{tabular}{|l|l|l|l|l|}
\hline Unity & Spelling & Title & Introduction & Brainstorming \\
\hline Transition words & $\begin{array}{l}\text { Supporting } \\
\text { sentences }\end{array}$ & Punctuation & Complete thought & Cohesion \\
\hline $\begin{array}{l}\text { Demonstrative } \\
\text { pronouns }\end{array}$ & $\begin{array}{l}\text { Concluding } \\
\text { sentence }\end{array}$ & Personal pronouns & Controlling ideas & Organization \\
\hline
\end{tabular}

1- In editing stage, the focus is on checking ....

and

2- The topic sentence is the first sentence and it is a

3- The body paragraph comes after.

4- $\ldots \ldots \ldots \ldots$ means discussing only one idea in the paragraph.

5 - The function of the $\ldots \ldots \ldots \ldots \ldots \ldots \ldots \ldots \ldots \ldots$ is to sign the closing of the paragraph.

6- The ..................... Is usually not a complete sentence.

7- ............................. is used to list ideas and thoughts about a topic.

8- Some devices to connect sentences while writing as and

Question Three: (15 marks)

write a complete paragraph about planning for your birthday party.

\begin{tabular}{|l|l|l|l|l|}
\hline Grammar & Vocabulary \& spelling & Ideas \& Cohesion & Punctuation \& layout & Unity of Paragraphs \\
\hline & & & & \\
\hline Total 15
\end{tabular}

Question Three: (25 Marks)

Write an essay of three paragraphs about one of the following topics:

- Shopping at big molls.

- Modern technology in our life

- Teaching English as a career.

\begin{tabular}{|l|l|l|l|l|}
\hline Grammar & Vocabulary \& spelling & Ideas \& Cohesion & Punctuation \& layout & Unity of Paragraphs \\
\hline & & & & \\
\hline Total 25 & & & \\
\hline
\end{tabular}

\section{Best of Luck}

APPENDIX (3) Questionnaire of Students' Feeling and Satisfaction Towards Flipped Learning*

\begin{tabular}{|c|c|c|c|c|c|c|}
\hline $\begin{array}{l}\text { N. Of } \\
\text { Items }\end{array}$ & Statements & $\begin{array}{l}\text { Strongly } \\
\text { Agree }\end{array}$ & Agree & $\begin{array}{l}\text { Quite } \\
\text { Agree }\end{array}$ & Disagree & $\begin{array}{l}\text { Strongly } \\
\text { Disagree }\end{array}$ \\
\hline $1-$ & It was difficult to me to adjust to the flipped classroom. & & & & & \\
\hline $2-$ & I liked having the lecture out of the class time & & & & & \\
\hline 3- & $\begin{array}{l}\text { I liked working on the exercises and learning material in the class with the } \\
\text { teacher. }\end{array}$ & & & & & \\
\hline $4-$ & I prefer having the teacher during the exercises more that lecture time. & & & & & \\
\hline $5-$ & $\begin{array}{l}\text { I liked completing a task after watching the presentations and videos } \\
\text { before the class }\end{array}$ & & & & & \\
\hline 6- & The book was useless to me with the flipped classroom. & & & & & \\
\hline $7-$ & Flipping the class required me to change my leaming style and strategies. & & & & & \\
\hline 8- & $\begin{array}{l}\text { It was so fixable to watch and repeat leaming material before the class } \\
\text { time. }\end{array}$ & & & & & \\
\hline 9- & $\begin{array}{l}\text { It was difficult and not accessible for me to depend on online materials in } \\
\text { leaming. }\end{array}$ & & & & & \\
\hline $10-$ & It was difficult to me to understand the learning material alone at home. & & & & & \\
\hline $11-$ & $\begin{array}{l}\text { Class time was more useful to me more than before in the lecture-format } \\
\text { class. }\end{array}$ & & & & & \\
\hline $12-$ & $\begin{array}{l}\text { I liked the flipped class and prefer to have more flipped classes in the } \\
\text { future. }\end{array}$ & & & & & \\
\hline $13-$ & The course as a whole was easy and enjoyable. & & & & & \\
\hline
\end{tabular}

14- What the things you didn't like in this course?

15- What are the things you most liked in this course?

*The Questionnaire was available for the students in the two classes using the following links:

Advanced Writing: https://g0o.gl/forms/qMf9VcoI7N47CUiG3

Teaching English Language: https://goo.gl/forms/ePvMUglzfUAlzlRI3 


\section{Copyrights}

Copyright for this article is retained by the author(s), with first publication rights granted to the journal.

This is an open-access article distributed under the terms and conditions of the Creative Commons Attribution license (http://creativecommons.org/licenses/by/4.0/). 